\title{
Nutrient Dynamics in Open Field Floriculture: Some Thoughts
}

\section{Rokolhuii Keditsu*}

Department of Horticulture, School of Agricultural Sciences and Rural Development, Nagaland University, Nagaland, India

Occurrence of nutrient constraint at any phonological growth stage on multi-nutrient deficient soils could jeopardize the incentives accruing through otherwise balanced fertilization in highly diversified nutrient demanding flower varieties [1]. The current state of knowledge on the subject, especially under open field conditions is very limited, although, technology for protected cultivation using hydroponics is very well established $[2,3]$. The subject relating open field Floriculture becomes still very complex in the absence of knowledge on kinetics and co-kinetics of different nutrients being partitioned across different growth stages so that the growth stage wise nutrient demand is precisely determined, and accordingly type and source of nutrients are fed synchronising the physiological nutrient demand. Development of microbial consortium (microbial reactor) exploiting the native and natural microbial synergisms (with twin role as growth promoter and antagonistic to soil borne pathogens) is one of the popular methods of providing the desired dynamism to nutrient dynamics within the rhizosphere. Such rhizosphere specific consortia could further engineer rhizosphere's nutrient demand and supply through loading with organic manures in much value added form Longchar and Keditsu [4]. The efforts such as these could only meet their objectivity unless duly supported by an efficient nutrient diagnostics applicable under varying field conditions.

Development of cultivar specific norms nutrient norms (e.g., optimum level of leaf $\mathrm{N}, \mathrm{P}$ and $\mathrm{K}$ were determined as $2.22-2.56 \%$, $0.18-0.25 \%$ and $1.80-2.20 \%$, respectively, for open field Gerbera) and soil test rating besides microbially loaded substrate for crop like mushroom need a thorough revisit and to be field validated in order to provide their application at regional level [3]. A good success on these aspects has been achieved in grape, mango, citrus, papaya, banana, guava, sapota, and pomegranate. However, the major point of discontent still does not remain to be warded off with respect to whether nor not different nutrient norms are required as per cultivar within the same variety. The biggest constraint on the other hand in making soil test ratings more purposeful is the non-redressal of spatial variation in soil fertility. Conjoint use of geoinformatics (Geographical Information System, Global Positioning System, Hyperspectral Remote Sensing) and site specific nutrient management strategy exploiting spatial variability in soil fertility have offered an easier method of combating the such pivotal factors driving to reduced fertilizer use efficiency. Sensorbased technology has further added a new dimension in providing the nutrient supply as per canopy size in time domain manner using programmable multi-channel fertigation. Application of open field hydroponics is the starting point to adopt such improvised production technologies. However, it remains to be seen in different flower crops, do we need a different nutrient levels vis-à-vis critical growth stages so that a complete cropwise nutrient logging studies ease out the so called complexity in understanding the nutrient dynamics in flower crops which remained an under-focussed issue for a quite long time $[5,3]$. Extending vase life through nutrient-water synergy has to be viewed afresh through desired changes in scavenging impact on reactive oxygen species vis-à-vis antioxidant profiling.

\section{References}

1. Keditsu R (2012a) Response of Gerbera to inorganic fertilization versus organic manuring. Ann PI Soil Res 14: 163-166.

2. Keditsu R (2012) Agronomic performance and variation of flower characteristics of gerbera under varying soil condition and open field cultivation. J Agric Physics 12: 1-12

3. Keditsu, Rokolhuii (2013b) Gerbera Nutrition. Lambert Academic Publishing, Germany, 1-276.

4. Longchar A, Keditsu R (2013) Flower yield and vase life of Gerbera in response to planting time and organic manures on Alfisol. Sci J Agric 2: 124-128.

5. Keditsu R (2013a) Gerbera: Soil fertility and plant nutrition. Sci J Agric 2: 97 114
*Corresponding author: Rokolhuii K, Department of Horticulture, School of Agricultural Sciences and Rural Development, Nagaland University, India, E-mail: rokokdts@yahoo.com

Received June 06, 2013; Accepted June 08, 2013; Published June 15, 2013

Citation: Keditsu R (2013) Nutrient Dynamics in Open Field Floriculture: Some Thoughts. Agrotechnol 2: e105. doi:10.4172/2168-9881.1000e105

Copyright: @ 2013 Keditsu R. This is an open-access article distributed unde the terms of the Creative Commons Attribution License, which permits unrestricted use, distribution, and reproduction in any medium, provided the original author and source are credited. 